\title{
Primary Neoplasms of the Lung in Children and Adolescents: 22 Cases from a Single Institute
}

Purpose: Primary lung tumors in children and adolescents are uncommon. We report here on the clinical presentations, the methods of treatment, the results and the outcomes of a series of children with these rare tumors. Materials and Methods: We conducted a retrospective review on all the patients less than 19 years of age with primary lung tumors and who were treated at Samsung Medical Center between 1995 and 2009. Twenty two cases of primary lung tumors were reviewed and the clinical-pathological information concerning the tumor characteristics, the therapy and the follow-up was collected. Results: The average age of the 10 male patients and 12 female patients was 11.5 years (range: 3 months to 18 years). Of the 22 primary lung tumors, $18.2 \%(4 / 22)$ were benign, $36.4 \%(8 / 22)$ were of borderline malignancy and $45.4 \%(10 / 22)$ were malignant. The pathologic types were inflammatory myofibroblastic tumor (6/22), mucoepidermoid carcinoma (4), pleuropulmonary blastoma (2), adenocarcinoma (1), alveolar soft part sarcoma (1), malignant lymphoma (1), leiomyoma (1), pulmonary leiomyomatous hamartoma (1), congenital pulmonary myofibroblastic tumor (1), Langerhans' cell histiocytosis (1), neurilemmoma (1), sclerosing pneumocytoma (so-called sclerosing hemangioma) (1) and atypical carcinoid tumor (1). After surgery for the benign tumors, no postoperative recurrence was been observed during long-term follow-up. All the patients with the benign tumors were alive with no evidence of disease. For the patients with the tumors of borderline malignancy, one patient experienced recurrence, but there was no death from disease. For the group with malignant tumors, two patients died from untreatable metastatic disease and 8 patients survived their disease on the long-term follow-up. Conclusion: The primary lung tumors during childhood and adolescence had different characteristics compared with their adult counterparts with respect to the incidence and prognosis. These facts must be considered when making the diagnosis and deciding on proper therapy. (J Lung Cancer 2009;8(2):103-110)

Key Words: Lung, Neoplasms, Childhood, Adolescent

\author{
Jungsuk An, M.D. ${ }^{1}$ \\ Joungho Han, M.D., Ph.D. ${ }^{1}$ \\ Kang Mo Ahn, M.D., Ph.D. ${ }^{2}$ \\ Jhingook Kim, M.D., Ph.D. ${ }^{3}$ and \\ Yong Soo Choi, M.D., Ph.D. ${ }^{3}$
}

Departments of ${ }^{1}$ Pathology,

${ }^{2}$ Pediatrics and ${ }^{3}$ Thoracic Surgery, Samsung Medical Center, Sungkyunkwan University School of Medicine, Seoul, Korea

Received: November 25, 2009 Accepted: December 12, 2009

Address for correspondence Joungho Han, M.D., Ph.D.

Department of Pathology, Samsung Medical Center, Sungkyunkwan University School of Medicine, 50, Ilwondong, Gangnam-gu, Seoul 135-710, Korea

Tel: $82-2-3410-2800$

Fax: 82-2-3410-0025

E-mail: hanjho@skku.edu

\section{INTRODUCTION}

Primary lung tumors are rare in childhood and adolescence. Most masses in the lung turn out to be developmental or reactive lesions such as bronchogenic cyst, pulmonary sequestion, granulomatous inflammation and abscess, rather than a neoplasm (1). A study have reported a ratio of $1: 5: 60$ for primary pulmonary tumors to secondary neoplasms to non-neo- plastic disease entities in the pediatric lung (2). Primary lung tumors have been reported to account for only $0.2 \%$ of all pediatric malignancies (3). Most pediatric lung tumors are metastatic from non-pulmonary malignancies. Metastatic tumors from non-pulmonary primary neoplasms comprise approximately $80 \%$ of all pediatric lung tumors and more than $95 \%$ of malignant tumors of the lung in children (4). The predominant lung tumors in adults, namely brochogenic carcinoma, squamous cell carcinoma, and adenocarcinoma, are extremely rare in 
children and adolescents (5). The common primary lung tumors in children are pleuropulmonary blastoma (PPB), carcinoid tumor, myofibroblatic tumor, and mucoepidermoid tumor (MEC) (1).

Our report presents a series of 22 cases treated at the Samsung Medical Center (SMC), Seoul, South Korea, over a 15 -year period. The aim of this report was to review the clinical presentation, the histologic diagnosis and the treatment outcomes. We hope that our study will add to the cumulative knowledge about primary lung tumors in childhood and adolescence.

\section{MATERIALS AND METHODS}

We performed a retrospective review of all patients with primary lung tumors who were less than 19 years of age and were treated at the SMC from 1993 to 2009. Twenty two cases were identified from charts. Patients with primary tumors of the mediastinum and chest wall were excluded. There were no duplicate cases in the study sample. Clinical characteristics including age and gender of patients, the diagnostic methods, form of treatment, the location of recurrence, disease-free, and total survivals were recorded. The date of the lung biopsy was used as the date of diagnosis. The histological slides in each

Table 1. Primary Lung Neoplasms in Childhood and Adolescence: Samsung Medical Center, 1994 2009

\begin{tabular}{|c|c|c|c|c|c|c|c|c|c|}
\hline $\begin{array}{l}\text { Patient } \\
\text { No. }\end{array}$ & $\begin{array}{l}\text { Age at } \\
\text { diagnosis }\end{array}$ & Sex & $\begin{array}{l}\text { Pathologic } \\
\text { diagnosis }\end{array}$ & Location & $\begin{array}{l}\text { Diagnostic } \\
\text { work-up }\end{array}$ & $\begin{array}{l}\text { Surgical } \\
\text { procedure }\end{array}$ & Treatment & $\begin{array}{l}\text { Follow-up } \\
\text { (month)/ } \\
\text { Outcome }\end{array}$ & $\begin{array}{l}\text { Multiple } \\
\text { lesions or } \\
\text { lymph node } \\
\text { metastasis }\end{array}$ \\
\hline 1 & 7 & F & $\begin{array}{l}\text { Pleuropulmonary } \\
\text { blastoma }\end{array}$ & $\begin{array}{l}\text { Left lower } \\
\text { lobe }\end{array}$ & $\begin{array}{r}\mathrm{CT} \text {, frozen } \\
\text { diagnosis }\end{array}$ & $\begin{array}{l}\text { VAT's wedge } \\
\text { resection }\end{array}$ & $\begin{array}{l}\text { Combined } \\
\text { chemo- and } \\
\text { radiotherapy } \\
\text { after surgery }\end{array}$ & 160/NED & \\
\hline 2 & 9 & M & $\begin{array}{l}\text { Mucoepidermoid } \\
\text { carcinoma, } \\
\text { intermediate } \\
\text { grade }\end{array}$ & Trachea & $\begin{array}{l}\text { CT, } \\
\text { bronchoscopic } \\
\text { biopsy }\end{array}$ & $\begin{array}{l}\text { Tracheal } \\
\text { segmentectomy }\end{array}$ & $\begin{array}{l}\text { Surgery } \\
\text { only }\end{array}$ & 115/NED & \\
\hline 3 & 13 & M & $\begin{array}{l}\text { Adenocarcinoma, } \\
\text { poorly } \\
\text { differentiated }\end{array}$ & $\begin{array}{l}\text { Left upper } \\
\text { lobe }\end{array}$ & $\begin{array}{l}\text { CT, } \\
\text { bronchoscopic } \\
\text { biopsy }\end{array}$ & Lobectomy & $\begin{array}{l}\text { Combined } \\
\text { chemo- and } \\
\text { radiotherapy } \\
\text { after surgery }\end{array}$ & 16/DOD & $\begin{array}{l}\text { Lymph } \\
\text { node } \\
\text { metastasis }\end{array}$ \\
\hline 4 & 18 & F & $\begin{array}{l}\text { Alveolar soft part } \\
\text { sarcoma }\end{array}$ & $\begin{array}{l}\text { Both lung } \\
\text { fields }\end{array}$ & $\begin{array}{r}\mathrm{CT} \text {, frozen } \\
\text { diagnosis }\end{array}$ & $\begin{array}{l}\text { VAT's wedge } \\
\text { resection }\end{array}$ & $\begin{array}{l}\text { No further } \\
\text { treatment }\end{array}$ & 35/DOD & $\begin{array}{l}\text { Lung to } \\
\text { lung } \\
\text { metastasis }\end{array}$ \\
\hline 5 & 14 & M & $\begin{array}{l}\text { Inflammatory } \\
\text { myofibroblastic } \\
\text { tumor }\end{array}$ & $\begin{array}{l}\text { Left } \\
\text { bronchus }\end{array}$ & $\begin{array}{l}\mathrm{CT} \text {, } \\
\text { bronchoscopic } \\
\text { biopsy }\end{array}$ & $\begin{array}{l}\text { Bronchial } \\
\text { segmentectomy }\end{array}$ & Surgery only & 64/NED & \\
\hline 6 & 18 & M & $\begin{array}{l}\text { Inflammatory } \\
\text { myofibroblastic } \\
\text { tumor }\end{array}$ & Trachea & $\begin{array}{l}\text { CT, } \\
\text { bronchoscopic } \\
\text { biopsy }\end{array}$ & $\begin{array}{l}\text { Tracheal } \\
\text { segmentectomy }\end{array}$ & Surgery only & 38/NED & \\
\hline 7 & 11 & $\mathrm{~F}$ & $\begin{array}{l}\text { Mucoepidermoid } \\
\text { carcinoma, low } \\
\text { grade }\end{array}$ & $\begin{array}{l}\text { Right } \\
\text { bronchus }\end{array}$ & $\begin{array}{l}\text { CT, } \\
\text { bronchoscopic } \\
\text { biopsy }\end{array}$ & Lobectomy & $\begin{array}{l}\text { Chemotherapy } \\
\text { after surgery }\end{array}$ & 78/NED & \\
\hline 8 & 14 & M & $\begin{array}{l}\text { Pleuropulmonary } \\
\text { blastoma }\end{array}$ & $\begin{array}{l}\text { Right } \\
\text { middle } \\
\text { lobe }\end{array}$ & $\begin{array}{l}\text { CT, Gun } \\
\text { biopsy }\end{array}$ & $\begin{array}{l}\text { Lobectomy and } \\
\text { chest wall } \\
\text { excision }\end{array}$ & $\begin{array}{l}\text { Neoadjuvant } \\
\text { chemotherapy } \\
\text { after surgery }\end{array}$ & 74/NED & \\
\hline 9 & 9 & M & $\begin{array}{l}\text { Posttransplant } \\
\text { lymphoproliferative } \\
\text { disorder }\end{array}$ & $\begin{array}{l}\text { Both lung } \\
\text { fields }\end{array}$ & $\begin{array}{r}\text { CT, frozen } \\
\text { diagnosis }\end{array}$ & $\begin{array}{l}\text { VAT's wedge } \\
\text { resection }\end{array}$ & Chemotherapy & 69/NED & $\begin{array}{l}\text { Multiple } \\
\text { lesions } \\
\text { in liver } \\
\text { and } \\
\text { adrenal } \\
\text { gland }\end{array}$ \\
\hline
\end{tabular}


Table 1. Continued.

\begin{tabular}{|c|c|c|c|c|c|c|c|c|c|}
\hline $\begin{array}{l}\text { Patient } \\
\text { No. }\end{array}$ & $\begin{array}{l}\text { Age at } \\
\text { diagnosis }\end{array}$ & Sex & $\begin{array}{l}\text { Pathologic } \\
\text { diagnosis }\end{array}$ & Location & $\begin{array}{l}\text { Diagnostic } \\
\text { work-up }\end{array}$ & $\begin{array}{l}\text { Surgical } \\
\text { procedure }\end{array}$ & Treatment & $\begin{array}{l}\text { Follow-up } \\
\text { (month)/ } \\
\text { Outcome }\end{array}$ & $\begin{array}{l}\text { Multiple } \\
\text { lesions or } \\
\text { lymph node } \\
\text { metastasis }\end{array}$ \\
\hline 10 & 17 & $M$ & Leiomyoma & $\begin{array}{l}\text { Right } \\
\text { bronchus }\end{array}$ & $\begin{array}{l}\text { CT, } \\
\text { bronchoscopic } \\
\text { biopsy }\end{array}$ & $\begin{array}{r}\text { Bronchial } \\
\text { removal }\end{array}$ & Surgery only & 40/NED & \\
\hline 11 & 6 & $\mathrm{~F}$ & $\begin{array}{l}\text { Mucoepidermoid } \\
\text { carcinoma, low } \\
\text { grade }\end{array}$ & $\begin{array}{l}\text { Right } \\
\text { bronchus }\end{array}$ & $\begin{array}{r}\mathrm{CT} \text {, frozen } \\
\text { diagnosis }\end{array}$ & Lobectomy & Surgery only & 35/NED & \\
\hline 12 & 13 & $\mathrm{~F}$ & $\begin{array}{l}\text { Pulmonary } \\
\text { leiomyomatous } \\
\text { hamartoma }\end{array}$ & $\begin{array}{l}\text { Left lower } \\
\text { lobe }\end{array}$ & $\begin{array}{r}\mathrm{CT} \text {, frozen } \\
\text { diagnosis }\end{array}$ & $\begin{array}{l}\text { VAT's wedge } \\
\text { resection }\end{array}$ & Surgery only & 4/NED & \\
\hline 13 & 4 & $M$ & $\begin{array}{l}\text { Inflammatory } \\
\text { myofibroblastic } \\
\text { tumor }\end{array}$ & $\begin{array}{l}\text { Left } \\
\text { bronchus }\end{array}$ & $\begin{array}{r}\mathrm{CT} \text {, frozen } \\
\text { diagnosis }\end{array}$ & $\begin{array}{l}\text { Bronchial } \\
\text { segmentectomy }\end{array}$ & Surgery only & 31/NED & \\
\hline 14 & 16 & $\mathrm{~F}$ & $\begin{array}{l}\text { Inflammatory } \\
\text { myofibroblastic } \\
\text { tumor }\end{array}$ & $\begin{array}{l}\text { Left lower } \\
\text { lobe }\end{array}$ & $\begin{array}{r}\mathrm{CT} \text {, frozen } \\
\text { diagnosis }\end{array}$ & Lobectomy & $\begin{array}{l}\text { Surgery and } \\
\text { radiotherapy }\end{array}$ & $\begin{array}{l}\text { 19/Recur, } \\
\text { 28/NED }\end{array}$ & \\
\hline 15 & 0 & $\mathrm{~F}$ & $\begin{array}{l}\text { congenital } \\
\text { pulmonary } \\
\text { myofibroblastic } \\
\text { tumor }\end{array}$ & $\begin{array}{l}\text { Right } \\
\text { middle } \\
\text { and lower } \\
\text { lobes }\end{array}$ & $\begin{array}{r}\mathrm{CT} \text {, frozen } \\
\text { diagnosis }\end{array}$ & Lobectomy & Surgery only & 24/NED & \\
\hline 16 & 6 & M & $\begin{array}{l}\text { Langerhans' cell } \\
\text { histiocytosis }\end{array}$ & $\begin{array}{l}\text { Both lung } \\
\text { fields }\end{array}$ & $\begin{array}{r}\text { CT, frozen } \\
\text { diagnosis }\end{array}$ & $\begin{array}{l}\text { VAT's wedge } \\
\text { resection }\end{array}$ & Chemotherapy & 40/NED & $\begin{array}{l}\text { Multiple } \\
\text { lesions in } \\
\text { lung }\end{array}$ \\
\hline 17 & 16 & $M$ & Neurilemmoma & $\begin{array}{l}\text { Left } \\
\text { bronchus }\end{array}$ & $\begin{array}{l}\mathrm{CT} \\
\text { bronchoscopic } \\
\text { biopsy }\end{array}$ & Lobectomy & Surgery only & 1/NED & \\
\hline 18 & 10 & $\mathrm{~F}$ & $\begin{array}{l}\text { Inflammatory } \\
\text { myofibroblastic } \\
\text { tumor }\end{array}$ & $\begin{array}{l}\text { Right } \\
\text { lower } \\
\text { lobe }\end{array}$ & $\begin{array}{r}\mathrm{CT} \text {, frozen } \\
\text { diagnosis }\end{array}$ & Lobectomy & Surgery only & 30/NED & \\
\hline 19 & 12 & $\mathrm{~F}$ & $\begin{array}{l}\text { Sclerosing } \\
\text { pneumocytoma } \\
\text { (so-called } \\
\text { sclerosing } \\
\text { hemangioma) }\end{array}$ & $\begin{array}{l}\text { Left upper } \\
\text { lobe }\end{array}$ & $\begin{array}{r}\mathrm{CT} \text {, frozen } \\
\text { diagnosis }\end{array}$ & Lobectomy & Surgery only & 15/NED & \\
\hline 20 & 16 & $\mathrm{~F}$ & $\begin{array}{l}\text { Atypical carcinoid } \\
\text { tumor }\end{array}$ & $\begin{array}{l}\text { Right } \\
\text { bronchus }\end{array}$ & $\begin{array}{l}\mathrm{CT} \\
\text { bronchoscopic } \\
\text { biopsy }\end{array}$ & $\begin{array}{l}\text { Lobectomy after } \\
\text { bronchoscopic } \\
\text { removal }\end{array}$ & Surgery only & 19/NED & \\
\hline 21 & 13 & $F$ & $\begin{array}{l}\text { Mucoepidermoid } \\
\text { carcinoma, low } \\
\text { grade }\end{array}$ & $\begin{array}{l}\text { Right } \\
\text { bronchus }\end{array}$ & $\begin{array}{l}\mathrm{CT} \text {, } \\
\text { bronchoscopic } \\
\text { biopsy }\end{array}$ & $\begin{array}{l}\text { Lobectomy after } \\
\text { bronchoscopic } \\
\text { removal }\end{array}$ & Surgery only & 13/NED & \\
\hline 22 & 12 & $\mathrm{~F}$ & $\begin{array}{l}\text { Inflammatory } \\
\text { myofibroblastic } \\
\text { tumor }\end{array}$ & $\begin{array}{l}\text { Left upper } \\
\text { lobe }\end{array}$ & $\begin{array}{r}\mathrm{CT} \text {, frozen } \\
\text { diagnosis }\end{array}$ & $\begin{array}{l}\text { VAT's } \\
\text { segmentectomy }\end{array}$ & Surgery only & 12/NED & \\
\hline
\end{tabular}

CT: computed tomography, VAT: video assisted thoracotomy, NED: no evidence of disease, DOD: dead of disease.

case were reviewed for the record of pathologic features, and the accurate diagnosis was made based on recent WHO criteria. In our study, localized disease represents tumors confined to the lung, while regional disease is defined as tumor extending directly into adjacent organs or tissue and/or regional lymph nodes. Distant disease is defined as tumor spread to remote areas of the body during the perioperative period. 


\section{RESULTS}

Of all 22 cases, $45.4 \%$ were male (10/22) and $54.5 \%$ were female (12/22). The average age at diagnosis was 11.5 year-old (range, 3 months to 18 years). The various tumors encountered are summarized in Table 1. Of these primary lung tumors, $18.2 \%(4 / 22)$ were benign, $36.4 \%(8 / 22)$ were of borderline malignancy, and $45.4 \%(10 / 22)$ were malignant. The most common histologic type was inflammatory myofibroblastic tumor (IMT) in $27.2 \%(6 / 22)$. The next were MEC in $18.2 \%$ (4/22), and PPB in $9.1 \%$ (2/22). The other histological types of remaining cases were adenocarcinoma, alveolar soft part sarcoma, malignant lymphoma, leiomyoma, pulmonary leiomyomatous hamartoma, congenital pulmonary myofibroblastic tumor (CPMT), Langerhans' cell histiocytosis (LCH), neurilemmoma, sclerosing pneumocytoma (so-called sclerosing hemangioma), and atypical carcinoid tumor, each type reported in one case each.

Localized disease was present in $81.8 \%$ (18/22) of patients and regional disease was present in $9.1 \%(2 / 22)$ of patients. Distant disease was present in $9.1 \%(2 / 22)$ of patients. The distribution of the tumors within the lung was mainly lung parenchyme, 12/22; and mainly endobronchial or/and tracheal lumen, 10/22. The latter group included all four cases of MEC, half of IMTs (3/6), one leiomyoma, one neurilemmoma, and one atypical carcinoid tumor. Three patients had multiple lesions within the lung ( $\mathrm{LCH}$, alveolar soft part sarcoma and malignant lymphoma). Half of the patients (11/22) were diagnosed preoperately by percutaneous gun biopsy or bronchoscopic biopsy, while the remaining patients required video assisted thoracotomy (VAT)'s biopsy (4/22) or lobectomy $(5 / 22)$ or lung segmectomy (1/22), segmental resection of trachea and bronchus (1/22) for diagnosis. Most patients with endobronchial or tracheal mass were diagnosed by bronchoscopic biopsy (8/10). In one IMT and one MEC which represented endobronchial growth, bronchoscopic biopsy was not performed due to the possibility of complication such as bleeding.

Surgery, chemotherapy, and radiotherapy were the various treatment modalities used depending on the histologic subtypes (Table 1). Complete resection of the primary tumor was performed in total 19 patients, of which, 11 underwent lobectomy, 4 underwent bronchial or/and tracheal segmectal resection, 3 underwent VAT's wedge resection or segmentectomy, and 1 underwent bronchial resection. Among the patients in whom lobectomy was performed, one with PPB underwent chest wall excision for removal of a mass extending the chest wall as well as lobectomy. In 10 patients with tumor showing mainly endobrachial or/and tracheal growth, one of four patients with MEC and all three patients with endobronchial IMT underwent segmental resection of bronchus or trachea. Other two with MEC and one with neurilemmoma underwent lobectomy as initial surgical treatment, although the lesions were confined within the bronchial lumen. In the other one with MEC and one with atypical carcinoid tumor, lobectomy was performed because of incomplete bronchscopic removal of an endobronchial mass. One with leiomyoma underwent bronchoscopic removal of an endobronchial mass. In the three cases in which complete resection was not accomplished, one was a case of LCH with suspicious lesions in the liver and adrenal gland at the time of diagnosis, one was a case of malignant lymphoma, and one was a case of multiple alveolar soft part sarcoma.

Most patients (15/22) received no further treatment after complete resection of tumor, and the remaining patients received additional treatment, such as chemotherapy (4/22), radiation therapy (1/22), or combination of chemo- and radiation therapy (2/22). Only one of the four patients with MEC received chemotherapy after resection, while the other three patients had no more treatment after resection. In the group managed with chemotherapy, one of the two cases of PPB, one malignant lymphoma and one LCH were also included. The latter two patients received chemotherapy immediately after the diagnosis and were alive without evidence of disease at 69 and 40 month, respectively. The one PPB patient whose tumor invaded the chest wall received neoadjuvant chemotherapy before complete resection and there was minimal response to chemotherapy. After complete resection, the patient received adjuvant chemotherapy every three weeks for 10 months. The patient was alive 6 years following the chemotherapy without evidence of recurrence. The other patient with PPB was referred to the SMC for evaluation and treatment of a recurrent lesion after management for an initial lesion diagnosed five year ago. After wedge resection of the recurrent lesion, the patient was treated with combined chemo- and radiation therapy. The patient was alive 

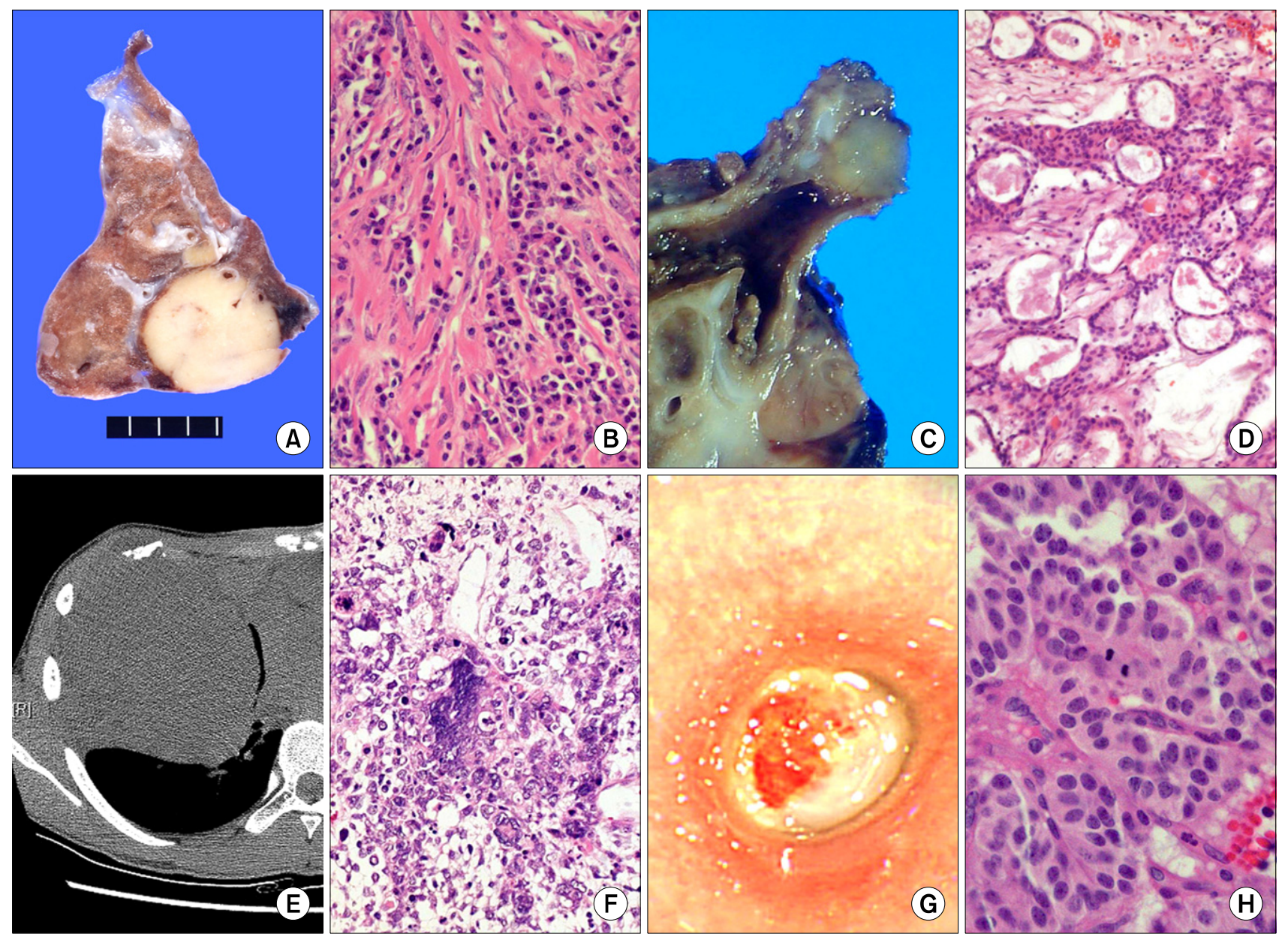

Fig. 1. Primary lung tumors of children and adolescents. (A, B) An inflammatory myofibroblastic tumor of a 12-year-old girl (patient 22). The segmentectomy specimen shows a well-demarcated solid mass at the periphery. It consists of myofibroblastic spindle cells with infiltrative plasma cells, lymphocytes and eosinophils. (C, D) A low grade mucoepidermoid carcinoma of a 6-year-old girl (patient 11). The mass occludes the right main bronchus. The tumor reveals a predominant cystic pattern of intermediate cells and occasional mucous cells with minimal cellular pleomorphism. (E, F) A pleuropulmonary blastoma of a 14-year-old boy (patient 8). The CT scan reveals a huge mass in the right mid-hemithorax. The mass is composed of solid sheets of primitive anaplastic cells that exhibits severe atypia and multinucleation without an epithelial component. $(G, H)$ An atypical carcinoid tumor of a 16-year-old girl (patient 20). Bronchoscopy reveals an obstructive endobronchial mass in the right bronchus. It shows ribbon-like or trabecular nests of monomorphic cells with rare mitosis (1/10 high powered fields).

and free from evidence of recurrence until follow-up period of 13 years.

For all 22 patients for whom follow-up data were available, the median follow-up length was 35 months. The 12 patients with non-malignant tumor had a median follow-up period of 27 months whereas the 10 patients with malignant tumor had a median follow-up period of 54.5 months. Two patients experience recurrence of their disease at 19 and 7 months. The patient with IMT had local recurrence and received radiotherapy after resection of the recurrent lesion. She was alive without evidence of disease at 28 months after the recurrence.
The patient with adenocarcinoma was managed by combined chemo- and radiotherapy after lobectomy. Seven months after the initial diagnosis, he had metastases in the lumbar spine and femur head. Although he was treated with radiation, no significant response for metastasis was noted and he died 9 months later. The aforementioned patient with unresectable multiple alveolar soft part sarcoma was treated unsuccessfully and died of disease 35 months after the initial diagnosis. As a result, 20 of the 22 patients with primary lung tumors were alive and well after a 36.5 month median follow-up. 


\section{DISCUSSION AND CONCLUSION}

Primary neoplasms of the lung represent rare lesions in childhood and adolescence. A study based on German registry data documented that $0.2 \%$ of all malignant tumors in children developed in the trachea, bronchus, and the lung parenchyma (3). According to a study by Neville et al. (6) on malignant pediatric lung neoplasms based on large population, the age-adjusted incidence was 0.049 per 100,000 persons. Although the incidence is rare, hundreds of cases have been described in the literature. The reported ratio of benign tumors to malignant tumors depends upon the method of investigation. In 1983, Hartman and Shochat (7) reported 230 primary tumors after a review of the medical literature. In 1993, Hancock et al. (5) reviewed the literature and published a subsequent report and identified a total of 383 childhood primary pulmonary neoplasms including the cases in the former report. These series using a review of the literature document that the majority of primary lung tumors are malignant $(67 \sim 76 \%)$. In addition to these literature review series, there are two studies from a single-institutional experience on pediatric lung tumor. These studies reported different results on ratio of benign to malignant tumors. In 1992, Cohen and Kaschula (2) published a review of 465 pediatric lung specimens from a tertiary care children's hospital in South Africa. Of the 43 pediatric lung tumors reported, 8 cases were primary lung tumors (four benign and four malignant) and the remaining cases were metastatic tumors to the lung. Another recent review of 227,655 specimens from a large children's hospital during 25-year period revealed a total of 204 lung tumors including 34 primary lung neoplasms and 170 metastatic lesions. Of primary lung neoplasms, 20 cases were benign and 14 cases were malignant. Our study found 4 cases of benign tumors, 8 cased of borderline malignancy, and 10 cases of malignancy during 15 years. The ratio of benign tumors to malignant tumors in our study is similar to the two previous series from single-institution experience. The most common diagnosis in our series was IMT, which constituted $27.3 \%$, followed by MEC (18.2\%) and PPB (9.1\%). In the study by Cohen and Kaschula (2), IMT (plasma cell granuloma) was the most common histology, seen in $37.5 \%$ of the patients $(3 / 8)$.

Although IMT rarely develops in adults, it has been reported as much as $57 \%$ of benign lung tumors in children (7). The lesion has also been named as inflammatory pseudotumor, fibroxanthoma, histiocytoma, and plasma cell granuloma (2). IMT consists of myofibroblastic spindle cells with infiltrative plasma cells, lymphocytes, and eosinophils (Fig. 1A, B) (8). This is an uncommon lesion reported in many organs and had been believed to be a non-neoplastic reactive inflammatory disease. The concept of benign lesion has been recently challenged from both clinical demonstration of recurrence and a molecular rearrangement on chromosome $2 \mathrm{p} 23$, the tyrosine kinase receptor anaplastic lymphoma kinase (ALK) involved in other malignant tumors (9). These tumors tend to be slowly growing and locally invasive. The series of pediatric lung tumors by Hartman and Shochat (7) reported four disease-related death in perioperative period and one recurrence in 45 IMT cases. The causes of death were tracheal obstruction or mediastinitis at diagnosis, but were not associated with recurrence. In the patients from our series, one patient had local recurrence and underwent surgical therapy and postoperative radiation therapy. The patient was well and free of evidence of disease. Because IMT can invade local structures and recur, the patients should be treated with complete excision when possible. This may entail lobectomy or pneumonectomy, and in some cases resection of surrounding structures. Adjuvant radiotherapy or chemotherapy has been employed but no specific regimen has gained widespread acceptacnce (8).

MECs are the second most common tumor in our series, consisting of three low grade cases and one intermediate grade case (Fig. 1C, D). They represented about $10 \%$ of primary pulmonary tumors of childhood (4). But the two singe-institutional studies revealed only one case or none of $\operatorname{MEC}(1,2)$. Other review of pediatric primary epithelial lung malignancies from a large hospital yielded only one MEC among 11 carcinomas (10). Tracheobronchial MET appears identical to the more common tumor arising in major or minor salivary glands. This develops from mucous glands of the respiratory mucosa or submucosa in trachea or main bronchial tree (8). The lesions are usually polypoid and are covered with respiratory epithelium. For this reason, bronchial biopsy is diagnostic and must be performed (11). In three out of our MEC cases bronchial biopsy was performed and exhibited a proper diagnosis. MEC of the lung can be divided into low grade or intermediate grade or high grade according to histologic 
features. Most MECs in children are low grade (11). These tumors are slowly growing and locally invasive, but the prognosis is good with complete excision. All of our four patients had good prognosis with no evidence of recurrence after lobectomy or segmental resection of trachea in a 35 months median follow-up.

PPB is a rare malignant mesenchymal tumor found in children which is quite distinct from the pulmonary blastoma of adults (12). It consists of polyphenotypic mesenchymal elements and embryonic stroma without a neoplastic epithelial component in contrast to the pulmonary blastoma (Fig. 1E, F). PPB is subclassified according to the proportion of cystic and solid areas: only cystic components (type I), cystic and solid components (type II), only solid components (type III) (13). PPB was reported to be the third most frequent $(15.5 \%)$ pediatric primary pulmonary malignancy in the previous series of literature review $(5,7)$. In the review studies of a single large hospital, PPB was the most common primary malignancy of lung with a proportion of $50 \%$ and $57.1 \%(1,2)$. Treatment for PPB is mainly surgical resection for the cystic and locally confined lesions with adjuvant chemotherapy in case with incomplete resection (1). The lesion with solid component or the presence of metastatic disease at diagnosis require additional chemotherapy, and radiotherapy $(1,14)$. The prognosis in patients with PPB is poor with mortality rates ranging from $60 \%$ to $95 \%$ at 5 years and only $8 \%$ at 10 years (8). One of two patients with PPB relapsed and underwent a combination of chemo- and radiotherapy after resection. The other patient received chemotherapy before operation because the tumor invaded the chest wall. Despite unfavorable conditions, both patients were alive with no evidence of disease at 160 months and 74 months, respectively, after the last surgical resection.

Although the vast majority of adult lung cancers are bronchogenic in origin, these tumors are extremely rare in children. We experienced only one case of poorly differentiated adenocarcinoma, stage IIIA (T2N2M0) in a 13-year-old boy. The tumor had a rapidly progressive course and the patient died with disseminated metastases despite adjuvant therapy. Due to the fact that bronchogenic carcinomas in childhood and adolescence are rare, it is not easy to make a comparison with a similar adult population. According to a few studies, these tumor in pediatric patients are generally metastatic at diagnosis with high mortality and average survival of 7 months $(5,7)$.
Because the studies emphasized that these tumors are associated with a high mortality, adjuvant or neoadjuvant therapy should be considered.

Primary lymphomas of the lung are extremely rare in children. Non-Hodgkin's lymphoma (NHL) can occur as a primary process in the lung or the lung may be involved as a site of metastasis. High-grade B-cell primary pulmonary lymphomas often occur in immunocompromised patients. Immunodeficiency states, including AIDS, congenital immunodeficiency, solid organ and bone marrow transplantation, carry a higher risk of lymphoma than the immunocompetent population (1). The most common immunodeficiency-related malignancies affecting the lungs are Kaposi's sarcoma, non-Hodgkin's lymphoma and, to a far less extent, Hodgkin's disease and bronchogenic carcinoma (15). An about $1 \%$ of allograft bone marrow transplants are at risk of NHL and this risk is increased in children. One of the complications arising in immunosuppressed recipients of solid organ or bone marrow transplants is posttransplant lymphoproliferative disorder (PTLD). In PTLD Epstein-Barr virus (EBV) proteins or EBV-encoded RNA are detectable in pathologic specimens and the EBV-driven B-cell proliferation is considered as the result of a multistep oncogenetic process triggered by EBV in chronically immunosuppressed patients (16). The patient with malignant lymphoma in our series was initially diagnosed as chronic myelogenous leukemia and managed with chemotherapy and bone marrow transplantation. Seven month later, he had multifocal nodular lesions in the lung, liver and adrenal gland. He was diagnosed as diffuse large cell lymphoma through VAT's lung biopsy. The presence of EBV was verified by in situ hybridization studies for EBV-encoded RNA on the lung tissue sections. The clinical course and pathologic features in this case were compatible with PTLD. The patient received chemotherapy and was alive with no evidence of disease 5 years after the diagnosis.

Carcinoid tumor is known to be one of the relatively common tumors in childhood $(5,7)$. According to the single-institution series the incidence of carcinoid tumor is similar to that of MEC (1,2). A large, population-based analysis revealed that pulmonary endocrine tumors, such as carcinoid tumors comprised $51.6 \%$ of all pediatric pulmonary malignancies (6). Carcinoid tumors are divided into two subtypes, typical and atypical with the latter exhibiting necrosis or an elevated mitotic index, and aggressive clinical behavior (11). Because 
of limited samples of this disease entity in childhood, this distinction may not correlate with clinical behavior. In other words, both subtypes may metastasize (8). Among pediatric patients local and/or distant metastasis rate of $27 \%$ has been reported (17). Our case of carcinoid tumor exhibited atypical features such as increased mitotic index (2/10 high powered field) and no recurrence in a 19 months follow-up (Fig. 1G, $\mathrm{H})$.

Tumors of the lung are extremely rare in the pediatric population. We found that $18.2 \%$ of pulmonary masses in the pediatric patient were benign, that $36.4 \%$ were of borderline malignancy, that $45.4 \%$ were malignant. The most common tumor was IMT, followed by MET. The third common malignant tumor was PPBs. To our knowledge, our study is the third report including only primary lung tumors in childhood and adolescence from a single institution. Diagnosis and treatment for tumors of the lung in childhood and adolescence may be difficult due to low patient numbers and deficiency of epidemiologic data. Because malignant lung tumors are relatively more frequent in young patients than in adults, a safe diagnosis should be made quickly and without delay. Furthermore, the primary lung tumors in children have a wide variety of histopathologic diagnoses and biologic behavior, mandating a broad range of treatment modalities. Although there is some overlap of histology types among children and adults, the tumor behavior and survival are often quite different. Survival rates vary considerably depending on tumor type, location, and stage. These facts have to be taken into account in diagnosis and therapy.

\section{REFERENCES}

1. Dishop MK, Kuruvilla S. Primary and metastatic lung tumors in the pediatric population: a review and 25-year experience at a large children's hospital. Arch Pathol Lab Med 2008; 132:1079-1103.

2. Cohen MC, Kaschula RO. Primary pulmonary tumors in childhood: a review of 31 years' experience and the literature. Pediatr Pulmonol 1992;14:222-232.

3. Tischer W, Reddemann H, Herzog P, et al. Experience in surgical treatment of pulmonary and bronchial tumours in childhood. Prog Pediatr Surg 1987;21:118-135.

4. Welsh JH, Maxson T, Jaksic T, Shahab I, Hicks J. Tracheobronchial mucoepidermoid carcinoma in childhood and adolescence: case report and review of the literature. Int $\mathrm{J}$ Pediatr Otorhinolaryngol 1998;45:265-273.

5. Hancock BJ, Di Lorenzo M, Youssef S, Yazbeck S, Marcotte JE, Collin PP. Childhood primary pulmonary neoplasms. J Pediatr Surg 1993;28:1133-1136.

6. Neville HL, Hogan AR, Zhuge $\mathrm{Y}$, et al. Incidence and outcomes of malignant pediatric lung neoplasms. J Surg Res 2009;156:224-230.

7. Hartman GE, Shochat SJ. Primary pulmonary neoplasms of childhood: a review. Ann Thorac Surg 1983;36:108-119.

8. Weldon CB, Shamberger RC. Pediatric pulmonary tumors: primary and metastatic. Semin Pediatr Surg 2008;17:17-29.

9. Griffin CA, Hawkins AL, Dvorak C, Henkle C, Ellingham T, Perlman EJ. Recurrent involvement of 2p23 in inflammatory myofibroblastic tumors. Cancer Res 1999;59:2776-2780.

10. Kantar M, Cetingul N, Veral A, Kansoy S, Ozcan C, Alper $\mathrm{H}$. Rare tumors of the lung in children. Pediatr Hematol Oncol 2002;19:421-428.

11. Al-Qahtani AR, Di Lorenzo M, Yazbeck S. Endobronchial tumors in children: institutional experience and literature review. J Pediatr Surg 2003;38:733-736.

12. Baraniya J, Desai S, Kane S, et al. Pleuropulmonary blastoma. Med Pediatr Oncol 1999;32:52-56.

13. Priest JR, McDermott MB, Bhatia S, Watterson J, Manivel JC, Dehner LP. Pleuropulmonary blastoma: a clinicopathologic study of 50 cases. Cancer 1997;80:147-161.

14. Parsons SK, Fishman SJ, Hoorntje LE, et al. Aggressive multimodal treatment of pleuropulmonary blastoma. Ann Thorac Surg 2001;72:939-942.

15. Cadranel J, Naccache J, Wislez M, Mayaud C. Pulmonary malignancies in the immunocompromised patient. Respiration 1999;66:289-309.

16. Muti G, Cantoni S, Oreste P, et al. Post-transplant lymphoproliferative disorders: improved outcome after clinico-pathologically tailored treatment. Haematologica 2002;87:67-77.

17. Lack EE, Harris GB, Eraklis AJ, Vawter GF. Primary bronchial tumors in childhood: a clinicopathologic study of six cases. Cancer 1983;51:492-497. 